\title{
Single-Phase Photovoltaic-Inverter Operation Characteristic in Distributed Generation System
}

\author{
Muh. Imran Hamid and Makbul Anwari
}

\begin{abstract}
Single-phase grid tied inverter is one among types of inverters widely used in photovoltaic (PV) generation system due to the advantages they offer. This chapter describes model and simulation of such inverter in operation as distributed generation in electrical power system. Power characteristics including power quality, grid interaction behavior and load sharing that are important aspects in their operation as grid connected inverter will be simulated and analyzed. The role of current or voltage control and associated mechanism in photovoltaic inverter such as photovoltaic I-V characteristic, maximum power point tracker (MPPT), and other mechanism that involves in power flow and load sharing control are described.
\end{abstract}

Further, some observation and measurement from a 5-kWp laboratory scale grid interconnected photovoltaic plant that employ single phase photovoltaic inverter will be presented. The load sharing behavior between photovoltaic plant and utility grid during supplying both linear and non linear load that connected on their point of common coupling. In addition, observation and measurement results of power quality parameter behavior during photovoltaic inverter operation along extremely density variation of photovoltaic produced energy that comes from the atmospheric condition will be presented.

Keywords: single phase PV Inverter, distributed generation

\section{Introduction}

Application of photovoltaic (PV) as a source of electrical energy showed a tendency to increase in terms of generation capacity and in terms of its spread in large areas around the world. Many aspects trigger the trend; economic, technology and policy are some among many. The restricted reserve of fossil fuel sources and followed by the increasing cost of fossil fuel based electricity generation has motivated the effort to exploit other alternative energy sources. In the other hand, the high price of equipment and system of photovoltaic generation as the main constraint on implementing this renewable generation system shows significant reduction during recent years; implicates to declination of production cost per $\mathrm{kW}$ electric from photovoltaic. IEA reported that over a decade (1996-2006), the price of photovoltaic system have decreased by probably more than $40 \%$ [1]. The maturity and 
continuously improved technology implemented on photovoltaic generation system that causes the photovoltaic power conversion more efficient, the typical advantages of PV generation compared with other electrical generation systems of renewable energy sources such as its flexibility and simplicity to build in any places, their dependency from transportation system are some technical factors causes the change to this type of renewable energy generation for electricity is preferred. In energy policy, environment issue and global warming as important consideration for the authority in deciding the choice of energy sources for their electricity make the photovoltaic generation system as the clean and convenient energy as one among priorities. Photovoltaic energy conversion becomes main focus of many researches due to its promising potential as source for future electricity.

The photovoltaic generation systems can either be operated as isolated system or be connected to the grid as a part of an integrated system, with other electrical generation, they form the distributed generation system. As renewable distributed generation, PV has some advantages if it is compared to other renewable energy generations. PV generation plant needs not a specific geographic or geo-morphological requirement such as on the wind and micro/small hydropower generation. In contrary, PV generation plant can be built in almost all area where the sun irradiation is available; allows the flexibility to determine the place of the plant according to its main allotment. The solar field and building integrated photovoltaic (BIPV) [2], [3] are some cases if the place- flexibility is taken as the advantage. In power system point of view, the place-flexibility of PV generation allows to employ the plant not only as power source for distributed generation, but can also as part of scheme for the transmission/distribution losses reduction [4], as compensator and power conditioner for the power system [5]. In addition, the module-based production of PV plant components that enables ones to build and adjust the size of PV plant from small capacity and then expand it to follow the demand growth is also one of advantages of this type of generation system. These entire make the PV generation becomes an interesting choice for development the distributed generation as direction of transition of the electrical power generation system [6].

However, besides the advantages, there are also several limitations of PV plant as electrical power generation for distributed generation. The reality that PV plant is built based on a number of power electronics equipment as the characteristic of renewable energy generation plant [7] causes the PV plant is considered as distortion and power quality problems source for the connected consumers or for electrical power component and system. Further, as the part of distributed generation, interaction with the power system component and load are also a factor influences the power quality resulted from PV generation plant operation. Regarding to these issues, some research has been conducted to investigate the effect PV generation connection to system, in [8] and [9], the harmonics effects of a large number PV inverter penetration in distribution network is analysed, the possibility of resonance event is found as the effect of interaction of harmonics produced from the inverters in the network. Injection of dc component in ac grid concerning to PV inverter integration have also reported in [10].

Other aspects that may influence the performance of PV generation for DG that should also be consider are: the effect of the extreme variation of power density variation in a range of hourly and daily as the nature of photovoltaic energy source, effect of PV plant 
configuration, type of PV inverter implemented, and interaction with the system in form of load flow and load sharing with grid. The influence of these aspects can be reviewed by analyzing the role of the PV inverter as the heart of a PV generation system. This chapter presents an analysis of performance and power quality aspect of operation a PV plant as distributed generation inverter concerning to their operation within dynamic atmospheric condition, the type of inverter used, their configuration with the photovoltaic array and their interaction with the grid parameters and loads. The single phase type PV inverter is stressed to be analyzed. A brief review of the PV generation systems and their setup components, and their potential to affect the quality of power output is firstly presented. Further, some measurement results from a laboratory scale generation system that show some power quality behaviors during plant operation are described and analyzed.

\section{Photovoltaic Generation System}

To analyze the power quality behaviors resulted from operation of a PV plant in distributed generation system, a review of the PV generation system and some aspects that involved in their operation as the part of the system must be done, they are: the PV module, PV inverter and the module-inverter configuration, the PV plant-grid interaction and the atmospheric condition. The main components of a PV generation plant are the PV modules and the PV inverters. The PV module is used as energy conversion equipment, converting the light energy to electrical form of the dc voltage and current. The conversion involves interaction process of the light, thermal and electrical parameters in a photovoltaic material. The PV inverter is then used to convert the $\mathrm{dc}$ to ac power to be used by consumer or to be connected to the grid. Some functions such as matching the array's dc voltage output with the inverter circuit voltage operation, matching the inverters' output voltage with the grid voltage and grid synchronizing are integrated in this compact equipment.

\subsection{PV Module}

Photovoltaic module is set up from formation of photovoltaic cells that convert the energy in the light to electric power. The modules are then arranged in both series and parallel configuration as a photovoltaic array to reach the voltage and current requirement. Photovoltaic cells are semiconductor devices that draws non-linear characteristics between output current $(I)$ and voltage $(V)$ on their terminal. In a condition when the light shapes their surface, the light generations current are produced in proportional to the light intensity, in the same time a dc voltage is generated. This condition presents the current source behavior of the cell. If the generated voltage is high enough, the solar cell current drops extremely, similar to the behavior of the diode as seen on the knee point of the diode's characteristic. From these behaviors, based on circuit perspective, photovoltaic cell can be modeled as configuration of current sources in parallel with some diodes, serial and parallel resistors are then added to present the voltage and current losses during cell operation. A photovoltaic cells model called the single diode model is widely used as shown in Fig.1. The model is a simplification of the two diode model by setting the value of ideality factor -a number that indicates the dominate region in a semiconductor material- of photovoltaic cell based on whether the diode's behavior of the cell is dominated by recombination or depletion region [11]. 


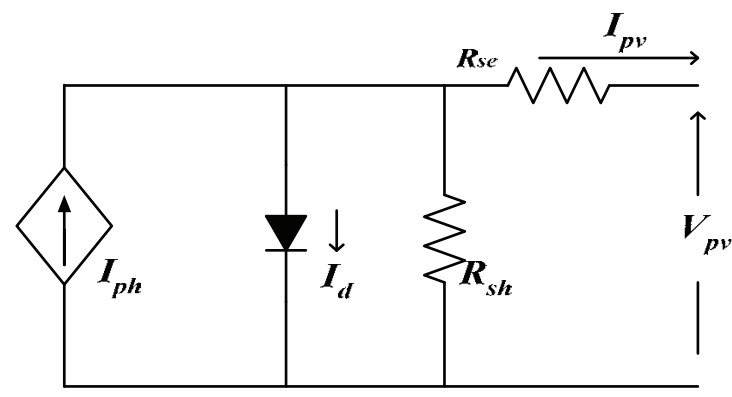

Fig. 1. Single diode model of a PV cell

This single diode model of PV cell can be described using the follows mathematical model to form the cell's $V-I$ characteristic as [12]:

Where

$$
\begin{gathered}
I_{p v}=I_{p h}-I_{d}-I_{s h} \\
I_{p v}=I_{p h}-I_{o}\left[e^{\frac{q\left(V_{p v}+I_{p v} \cdot R_{s e}\right)}{A_{o} k T}}-1\right]-\frac{\left(V_{p v}+I_{p v} \cdot R_{s e}\right)}{R_{s h}}
\end{gathered}
$$

$$
\begin{gathered}
I_{p h}=\left[I_{S C R}+K_{1}(T-25)\right]-\frac{G_{a}}{100} \\
I_{o}=I_{\text {or }}\left[\frac{T}{T_{r}}\right]^{3} \exp \left[\frac{q E_{G o}}{A_{o} k}\left(\frac{1}{T_{r}}-\frac{1}{T}\right)\right]
\end{gathered}
$$

$I_{p v}$ and $V_{p v}$ are the current and voltage of the PV cell. $I_{p h}$ is the light generating current, its value depends on irradiance and the physical dimension of photovoltaic cell, $\mathrm{I}_{\mathrm{o}}$ is the diode dark saturation current. The Boltzmann constant $=1.3807 \times 10^{-23} \mathrm{JK}^{-1}$ and electric charge $=$ $1.6022 \times 10^{-19} \mathrm{C}$ are presented by $k$ and $q . R_{s e}$ and $R_{s h}$ are the representation of the parasitic series and shunt resistances that associated with real solar cells in operation condition. $A_{o}$ is the diode ideality (quality) factor; its value is taken between 1 and 2, $A_{o}=1$ indicates that diode behaviour of cell is dominated by recombination in the quasi-neutral regions and $A_{o}=$ 2 indicates that recombination in the depletion region dominates. $I_{S C R}$ is short circuit current of the cell on $1000 \mathrm{~W} / \mathrm{m}^{2}$ and $25 \mathrm{OC}$ of temperature. $K_{1}$ is the short circuit temperature coefficient at $I_{S C R}$. $T$ and $G_{a}$ are cell temperature and irradiance on cell surface. $I_{o r}$ is the cell saturation current at reference temperature $T_{r}$. $E_{G O}$ is band gap energy.

Equation (1)-(4) shows the dependency of I-V characteristics of a photovoltaic cell to irradiance and temperature condition. The irradiance contributes to the cells current; the higher irradiance the higher current generates by the photovoltaic cell, while the temperature makes effect to the cell's voltage; the higher temperature the lower voltage appears on the cell's terminal. Figure 2(a) shows a set of I-V characteristics of a photovoltaic cell under varying irradiance, but at a constant temperature, while Fig. 2(b) shows the one at the same irradiance value, but under varying temperature. Both figures also show the points where the multiplication of voltage and current of PV cell reaches the maximum value; 
maximum power point (MPP). At these points, the PV cell operates in maximum efficiency and produces maximum output power for the related irradiances and temperatures.

\subsection{PV Inverter}

The second main components of the PV generation system are the PV inverters. This component interfaces the various power density generated by the photovoltaic array to the utility level of electrical power. As this role, some functions are employed: adjusting the voltage level of photovoltaic array output to meet the voltage operation of the inverter circuit; tracking the voltage/current to a point where maximum power can be extracted and creating sinusoidal ac power. If the PV inverter is used as grid tied PV inverter, it must be completed with a synchronizing and power flow control mechanism, a reliable protection, such as anti islanding to protect the inverter from over load, must be added. In addition, the modern PV inverter is also completed by an advanced data communication and monitoring system.
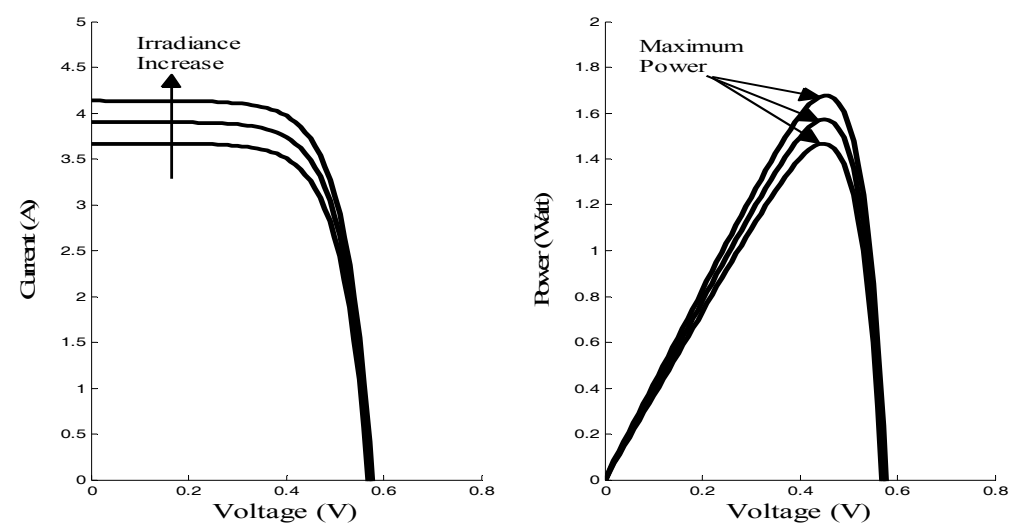

a. V-I characteristic on various irradiance and constant temperature
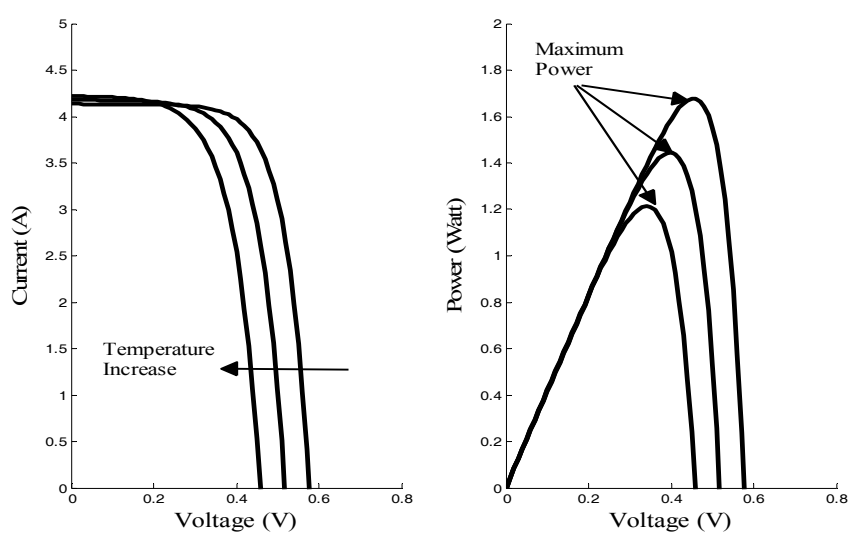

b. V-I characteristic on various temperature and constant irradiance

Fig. 2. $I-V$ characteristics of a photovoltaic cell under varying irradiance and temperature 
Maximum power point tracker (MPPT) is an important mechanism in a PV inverter; it is embedded to ensure that PV inverter extracts the optimum power generated by photovoltaic module or array. Cause of the unique properties of the PV array, when it is connected directly to a load, the operating point of the system lies on the crossing point of the $I-V$ characteristics curve of the PV array and $I-V$ characteristic curve of the load. Generally, this point is not at the PV array's maximum power point (Fig. 3), thus optimum extracted power cannot be achieved. In this case, to ensure that the load's power requirement can be supplied, a larger capacity of array is needed; leads to an expensive system. MPPT overcomes this problem, using certain algorithm, the mechanism forces the converter's voltage or current to operate on the value where the multiplication of array's voltage and current lie on the maximum condition, thus optimum power extraction can be achieved. The important role of the MPPT in PV inverter make this component becomes depth attention to the researchers, various techniques and development algorithms have been developed as in reference [13] and according to reference [14], the techniques can be categorized to three main categories: Look-up table, perturbation and observation $(\mathrm{P} \& \mathrm{O})$ and computational methods.

In a photovoltaic generation where the dc voltage output of PV array is not match with the associated ac voltage must be generated by the inverter circuit, DC-DC converter is implemented on the input side of the inverters' power circuit and the inverter system is called the multi stage PV inverter. Boost, buck and buck-boost or other types of DC-DC converter are used for this need. The MPPT mechanism in this case is implemented in the DC stage as direct duty cycle control for the DC-DC converter. Some types of multi stage PV inverter, for safety consideration, employ a transformer placed on the line side (LF transformer) or between power stages (HF transformer) of the inverter system.

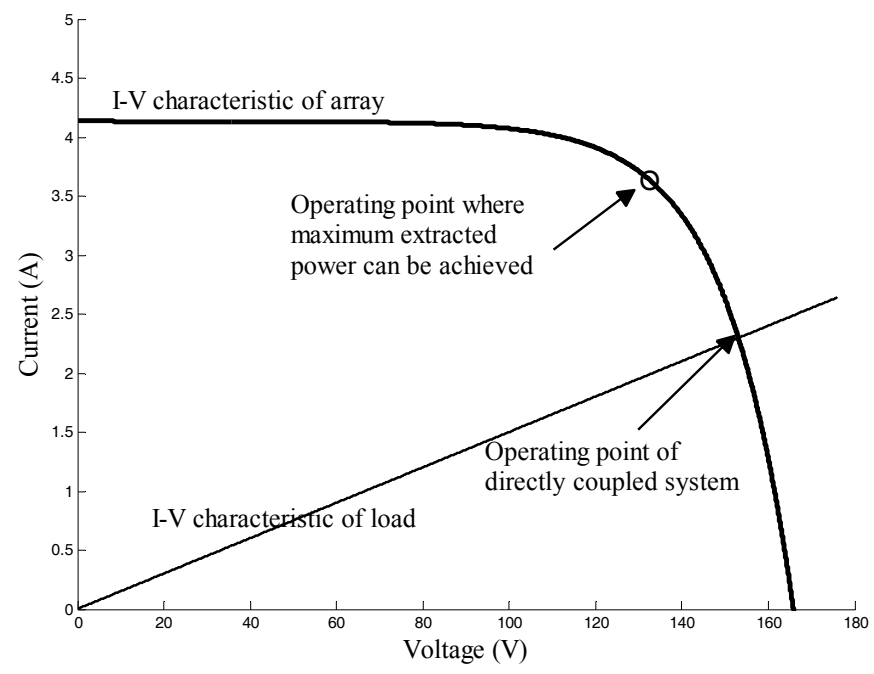

Fig. 3. Operating point of directly coupled system 
For the grid connected inverter (grid tied inverter), one among functions of control mechanism of PV inverter is aimed to ensure that all the generated power can be sent to the grid optimally, voltage and current control methods together with the MPPT are used for this requirement [15]. Protection mechanism such as anti islanding is added to avoid the PV inverter from overloaded condition when a fault exists on the grid. Synchronization with the grid is performed by various methods such as: by filtering the grid voltage, using PLL method, and using zero crossing detector based synchronization method.

\section{Array-Inverters Configuration}

From the overall requirements, the PV inverters are hoped to operate in optimum conversion efficiency. Photovoltaic material exploration, converter topologies and control mechanism have and being continuously developed. Development of power conversion efficiency can also be reached by optimizing the configuration between PV module/array and their associated PV inverter. Array-PV inverter configuration implicates to technical characteristic of plant such as voltage level, losses, reliability and power quality. In the real application, according to connection and configuration between PV module and PV inverter, photovoltaic generation can be identified as [16]:

Photovoltaic generation using central PV inverter, this configuration is reached by paralleling some PV module strings (some PV modules in serial connection) and connected to dc side of a relatively large capacity PV inverter. High conversion efficiency can be reached by using this configuration but faces a weakness along with diversity of PV module types and diversity of irradiance or partial shading. This configuration is also susceptible to reliability problem because the plant depends on single equipment only. Central inverter configuration is often implemented in a high capacity generation plant to optimize the cost, even though tend to limit the flexibility for adjusting plant capacity.

Photovoltaic generation using string $P V$ inverter, to overcome the weakness of central inverter configuration, the string PV inverter configuration was introduced. Each module string is connected to one inverter with own MPPT. Optimum power extracting from each string can be achieved, overall efficiency is better and PV generation reliability is increased because the system is not depend to only one equipment anymore. Plant capacity is also easy to adjust to follow demand growth.

Photovoltaic generation using multi-string PV inverter, this configuration is developed to adopt the cost and technical advantageous of both previous configurations. Some module strings with dc-dc converter and their own MPPT mechanism are connected to one inverter. Optimum power extracting from each module string can be achieved and in other side reduced cost for dc-ac converter can be done. This configuration allows using various types of inverter, various modules with different electrical characteristic and configuration.

Photovoltaic generation using team system, even though optimum power extraction can be achieved using multi-string PV inverter configuration, but implementation of single dc-ac converter in second stage of electrical conversion in other hand will decrease the reliability of generation system. Team system configuration was introduced to solve this problem, this configuration contains several module strings and its own PV inverters set up in parallel. When irradiance high enough, each module strings and its own inverter work 
independently for injecting power to ac side, on the contrary, if the irradiance goes down, module string configuration is changed in such a way so that not all of dc-ac converters operate. This scheme ensures that dc-ac converter always operates around their rated power.

Figure 4 illustrates the above configurations of PV generation system. In addition, module integrated PV inverter; a system in which a PV inverter is designed with its associated module specifically is also being developed. The string PV inverter, influenced by cost consideration, plant capacity, and flexibility to enlarge the plant capacity have widely implemented and become standard PV system technology for grid connected PV generation plant [17].

\section{Central Inverter \\ Configuration}

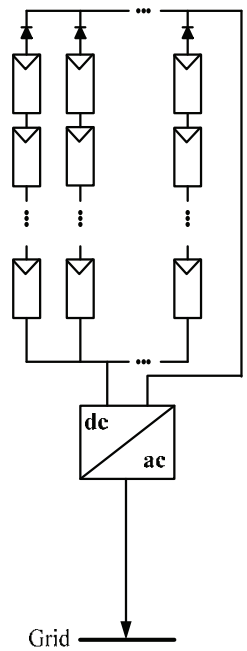

String Inverter

Configuration

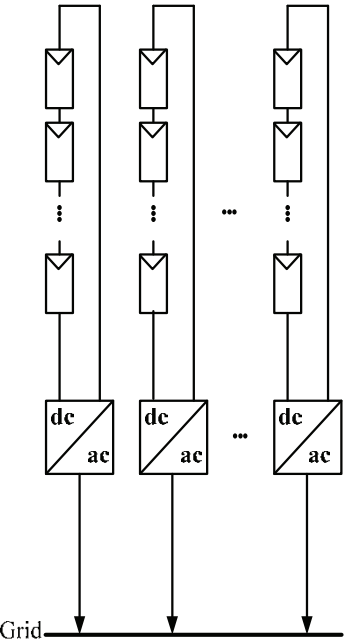

Multi-string Inverter

Configuration

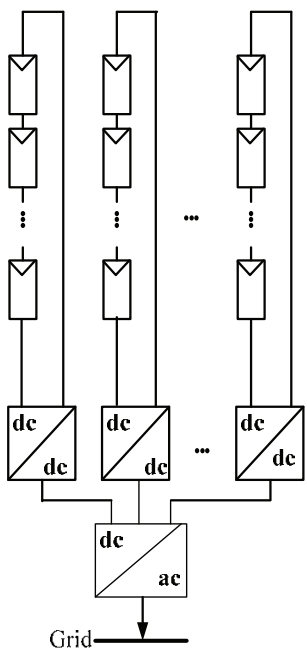

Team concept

Configuratior

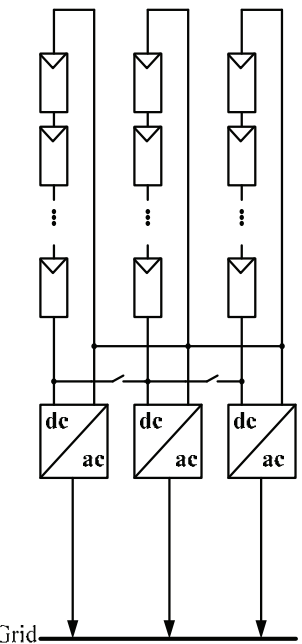

Fig. 4. Some PV module configurations in a PV plant $[16,17]$

\section{Single Phase Photovoltaic Inverter}

Along with the development and diversity application of photovoltaic as electrical source cause the PV inverters also spread to various types with the trend of single phase application. Single phase PV inverter has advantageous in flexibility for connecting to both single phase and three phase grid (three phase connection is formed by connecting at least three unit single phase inverters); this trend is also influenced by trend of PV generation plant configuration, as has been be discussed. For single phase application, PV inverter can be categorized in many point of views, in [18] single phase inverter is categorized based on the number of power switch that used and the number of power conversion sequences, while in [19] categorizing is done according to the number of power stages in cascade, type of power decoupling between the PV modules and the single-phase grid, is it utilizes a 
transformer or not and the types of grid-connected power stage. Figure 5 shows the diagram of some functions in a single phase PV inverter.

In the markets, PV inverters are found as a three-phase or single-phase unit, both in isolated and grid tied connection type. The three phase PV inverters are produced in relatively high capacity and used for large power application such as central inverter in a PV generation plant. Whereas, the single phase inverters are generally produced as string inverter in lower capacity, used in small power application such as in building photovoltaic system or in individually residential photovoltaic electricity. In a PV generation plant using single phase inverters, enlarging the plant capacity is done by implementing a number of PV inverters and connecting them to form the three phase connection.

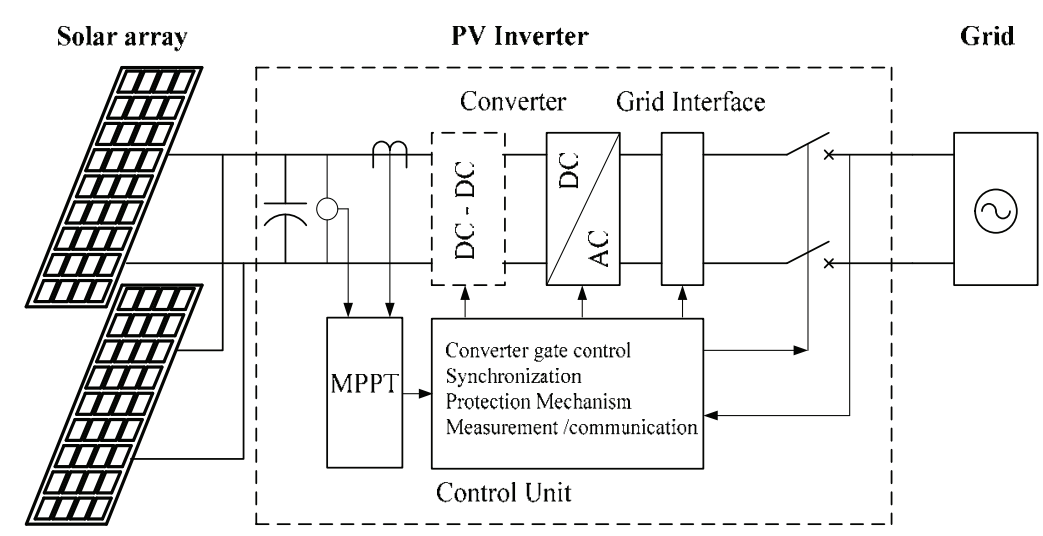

Fig. 5. Diagram of some functions in a single phase grid-tie PV inverter

\section{Simulation of photovoltaic generation using single phase inverter}

\subsection{Photovoltaic characteristic generator model for simulation}

One important aspect in photovoltaic generation study is to simulate the electrical parameter characteristic of photovoltaic module as the power source converter. The first step have to do is to model the characteristic relation of module/array output parameters (voltage and current) and input parameter (irradiance, temperature, humidity, etc) in form of mathematical model that can be use in digital simulation. Regarding to this, some approach can be done, mathematical model can be obtained from empirical characteristic of the array [20], here the model is built based on data from direct measurement of photovoltaic array's voltage/current in various inputs condition, model is then derived from plotted curve that describes voltage/current relation with the input parameter. If photovoltaic modules come with the $I-V$ characteristic curve, mathematics model can also be derived from that curves. Other approach is by modeling the module/array characteristic based on the equations that present the physical behavior of the photovoltaic cell; involves the relation between light, thermal and electrical parameters [21]-[23], and such approach is indicated by Eq. (1)-(4). 
Generally, as shown by Eq. (1)-(4), mathematic model obtained from described methods are in form of implicit and exponential equations that difficult to be solved and simulated. Therefore using Matlab/Simulink, to solve and simulate such model, the photovoltaic array equations are presented using several blocks, arranged such way so that implicit equation can be solved. An S-Function file is built in a block to solve numerically the photovoltaic cell characteristic equation and to synthesize the cell equation as array characteristic equation that contains of photovoltaic cell and module. If photovoltaic module contains $N_{s}$ cells in series and $N_{p}$ cell in parallel, thus (2) become:

$$
I_{p v}=N_{P}\left\{I_{p h}-I_{o}\left[e^{\frac{q\left(\frac{V_{p v}}{N_{S}}+\frac{I p v \cdot R_{s e}}{N_{p}}\right)}{A_{o} k T}}-1\right]\right\}-\frac{\left(\frac{V_{p v}}{N_{s}}+\frac{I_{p v} \cdot R_{s e}}{N_{p}}\right)}{R_{s h}}
$$

Simulation block of the PV array characteristic generator can be seen on Fig. 6. It is drawn as an S-Function block connected to a controlled current source block. As the input of SFunction blocks are the irradiation, temperature, and a loop of one-sample delayed voltage data from the output of whole PV array characteristic block generator. The loop is used to solve the implicit function in the $V-I$ characteristic equation of the array. Output of the SFunction block is used to drive the controlled current block so that the entire blocks configuration present a controlled current source characteristic of the PV array for used in time domain simulation.

To evaluate the performance of Simulink block of PV array model, the block model is simulated as follow:

two $I-V$ curves; $I(V)$, in different irradiance value according to Eq. (5) are plotted on an $i-v$ plane. With the same temperature value, the Simulink block of array model and connected load are then run, firstly with the irradiance value is similar to one used in plotting the curve on $i-v$ plane, voltage level and generated current as the array operating point is marked. Then, during simulation is running, the value of irradiance is changed to the value used to plot the second curve in same $i-v$ plane, operating point is marked once again. For both conditions, the operation marked points should be lie on a point along the corresponding $I-V$ curve. 

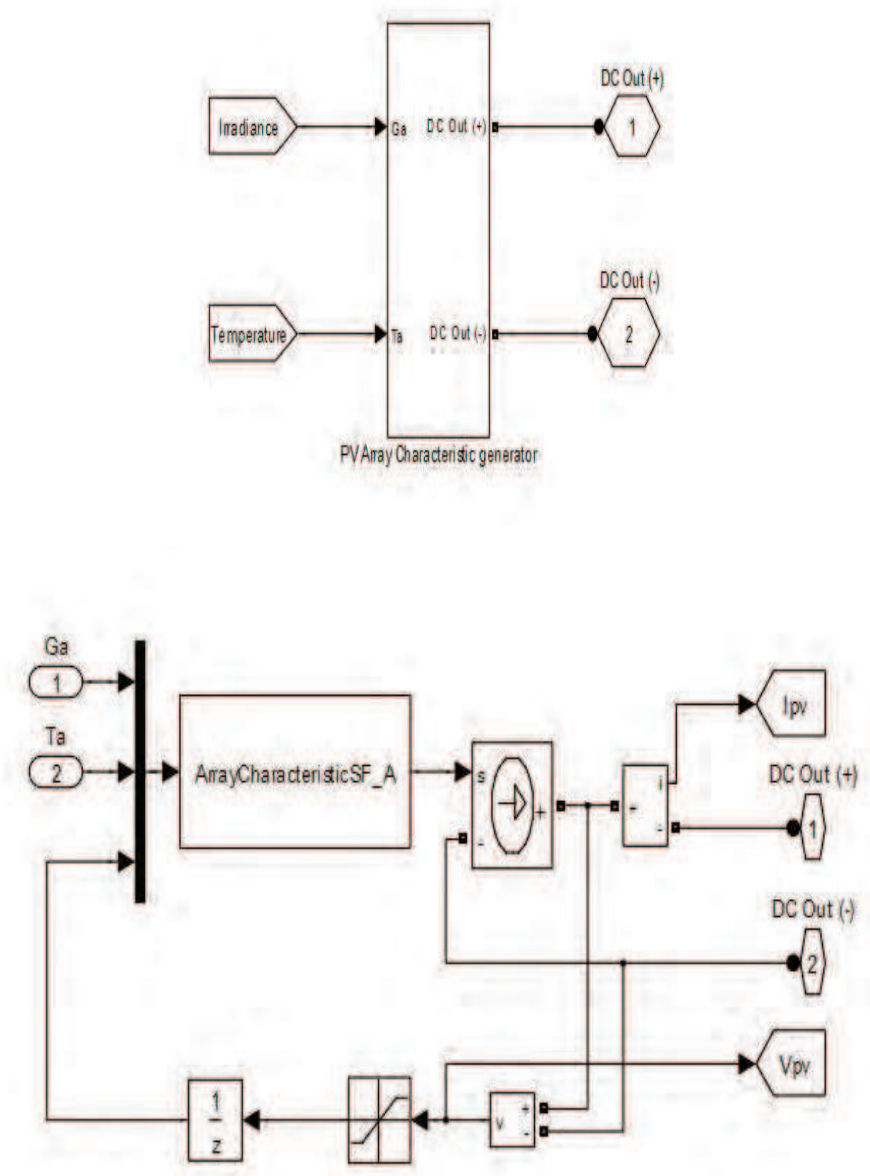

Fig. 6. Simulation block for the PV array characteristic generator in Simulink

Figure 7 shows the result of the treatment; $I-V$ characteristic curves are plotted with 500 and $1000 \mathrm{~W} / \mathrm{m}^{2}$ of irradiances and in same temperature of $25{ }^{\circ} \mathrm{C}$. The PV array block model then is run with connected load of $10-\mathrm{Ohm}$ impedance. Figure 7(b) and 7(c) are taken from running the array block in Simulink, for irradiance as $500 \mathrm{~W} / \mathrm{m}^{2}$ on temperature $25 \mathrm{OC}$, it shows that the connected load causes photovoltaic array operates on $31.36 \mathrm{Volt}$ and supplying 3.129 A of current. If irradiance is increased to $1000 \mathrm{~W} / \mathrm{m}^{2}$ on same temperature, the array operating point will shift to 32.01 Volt and 3.2 A. As supposed, these values are precisely located at a point along $I-V$ characteristic curve of photovoltaic array as shown on Fig. 7(a) as detail portion of Fig. 10(d). 


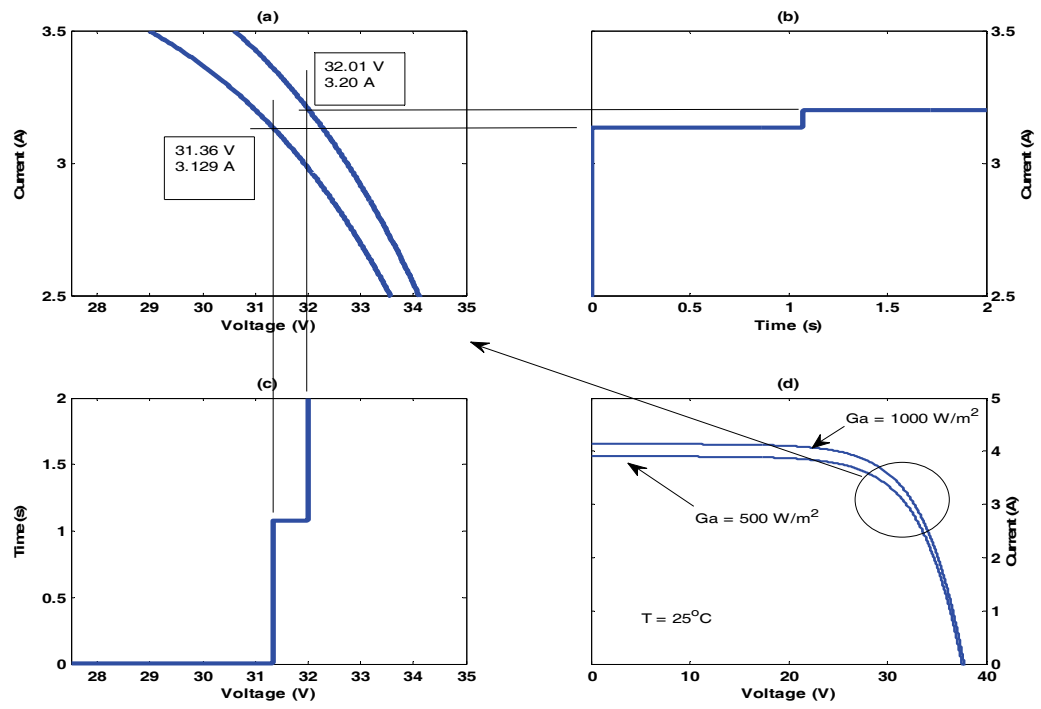

Fig. 7. PV array operation point obtained from plotting PV equation characteristic and from simulation in Simulink

\subsection{Power and control circuit}

Power converter block contains of the inverter power and control circuit. Inverter power circuit is set up from a coupling capacitor as power balancing for the instantaneous generated and delivered power to the grid, a single-phase bridge inverter circuit block controlled by PWM mode, an output filter, and a grid connection trough a step up transformer for matching the photovoltaic plant and grid voltage. Control circuit contains maximum power point (MPPT), current control and synchronizing block. In this case, the incremental conductance algorithm is used for the MPPT; as illustrated in Fig. 8, this algorithm works based on the condition that at the point of maximum power, the rate of change of output power to the array voltage is zero:

$$
\begin{gathered}
\frac{d P}{d V}=0 \\
\frac{d P}{d V}=\frac{d(V I)}{d V}=I+V \frac{d I}{d V}=0 \\
I+V \frac{d I}{d V} \cong I+V \frac{\Delta I}{\Delta V}=0 \\
\frac{\Delta I}{\Delta V}=-\frac{I}{V}
\end{gathered}
$$




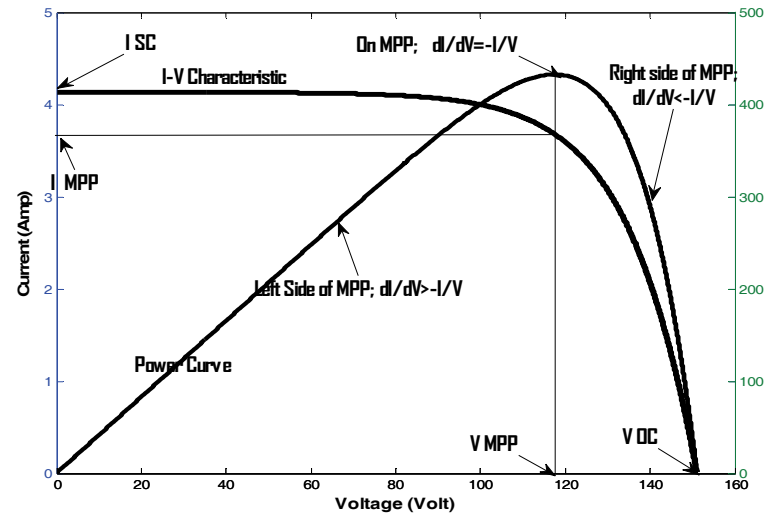

Fig. 8. Increment conductance $\Delta \mathrm{I} / \Delta \mathrm{V}$ around characteristic curve of photovoltaic array

On the maximum power point, the value of incremental conductance $\Delta I / \Delta V$ is $-I / V$ and varies around it as see on array characteristic curve, briefly:

$$
\begin{array}{cc}
\frac{\Delta I}{\Delta V}=-\frac{I}{V} & \text { on MPP } \\
\frac{\Delta I}{\Delta V}>-\frac{I}{V} & \text { on the left of MPP and } \\
\frac{\Delta I}{\Delta V}<-\frac{I}{V} & \text { on the right of MPP and }
\end{array}
$$

Flowchart of the incremental conductance algorithm is shown on Fig.9. 


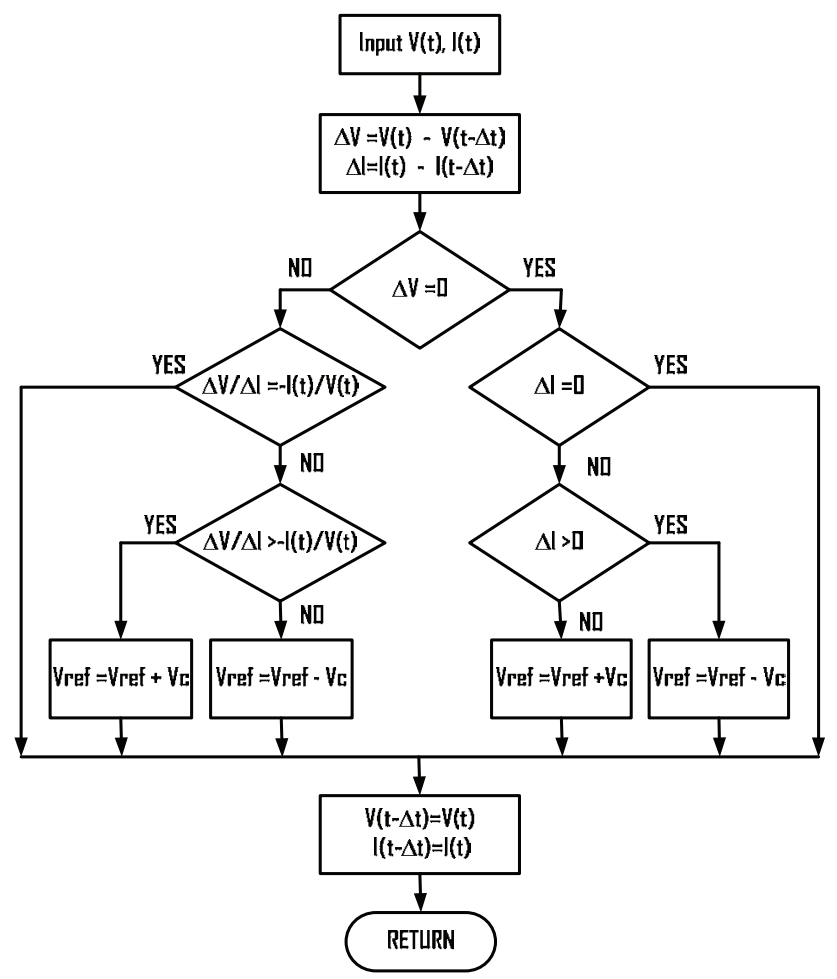

Fig. 9. Incremental conductance algorithm flowchart

In simulation, the algorithm is implemented in a S-Function block with the instantaneous current $I(t)$ and voltage $V(t)$, and each of their previous value in one sample time $\Delta t$ are used as inputs signal. The algorithm than calculates the increment conductance and evaluates it according to Eq. 7, the result is used to determine if the correction voltage $V_{C}$ for reference voltage $V_{\text {ref }}$ become positive or negative. An initial array voltage is required for this algorithm; values of 0.7 or $0.8 \mathrm{~V}_{\mathrm{NL}}$ (No load voltage) are preferred values. The error between $V_{\text {ref }}$ and actual PV array voltage is then used by controller to form reference current for inverters' current controller after added by actual current reference generated from power calculator block. Power calculator is a block where the instantaneous generated power in the array is calculated. Implementation of current control has an advantageous that current can be controlled independently from grid voltage, thus active and reactive power and certain power factor level is allowed in all range of load [15]. Reference current as the output of MPPT block is fed to current control block where the switching instant of the inverter switch is formed. In current control block, reference current determines the magnitude of injected current, while angle and current shape is determined by generated sinusoidal wave from the phase lockup loop (PLL) block. PLL operates by continuously observe the phase angle of grid voltage and compare it with an internally generated angle, a loop control is employed so that a reference phase angle can be determined according to grid phase voltage. 
To perform the switching instant for current control, some modulating techniques can be used; here the hysteresis and ramp comparison current control [24], is taken as the case, Fig.10. By using hysteresis current control, inverter output current is forced to follow the current reference. Deviation between these two quantities is limited by upper and lower band in a hysteresis loop. If actual current reaches the upper limit of hysteresis band, the inverter leg is switched off so that the current decrease untill reach the lower band of hysteresis loop. In this point, the inverter leg is switch on again and actual current back to increase to the upper band, the process repeat continuously. If ramp comparison current controller is used, a sinusoidal-wave signal is added to a triangle signal for creating a sinusoidal-triangle reference. This reference is then compared with the actual current. The instant when the sinusoidal-triangle wave and the actual current crosses becomes time when the inverter legs are switched. If the current error greater than sinusoidal-triangle wave, the inverter leg is switch off and in contrary if the current error less than sinusoidaltriangle then the inverter leg is switch on.

As the end of power circuit, a step up power transformer is used to connect the PV inverter circuit to the grid. Three-phase connection is formed by connecting at least three unit singlephase inverters that connected to each phase of the grid. Inverters in this configuration operate independently with their own control. Control signal for each PLL block in each inverter are picked from each grid phase. Complete simulation block diagram is shown in Fig. 11.
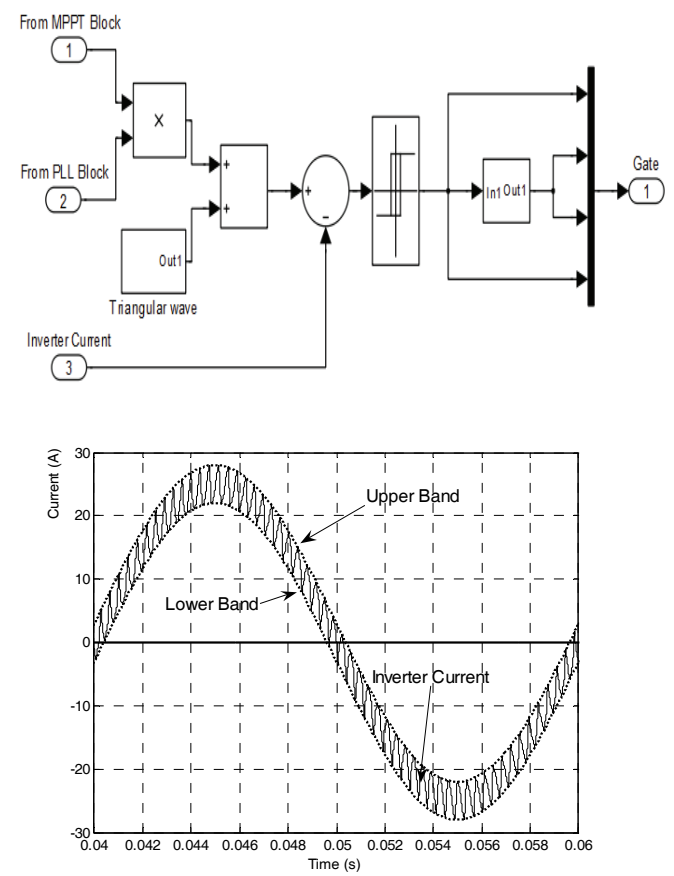

a. Hysteresis current control 

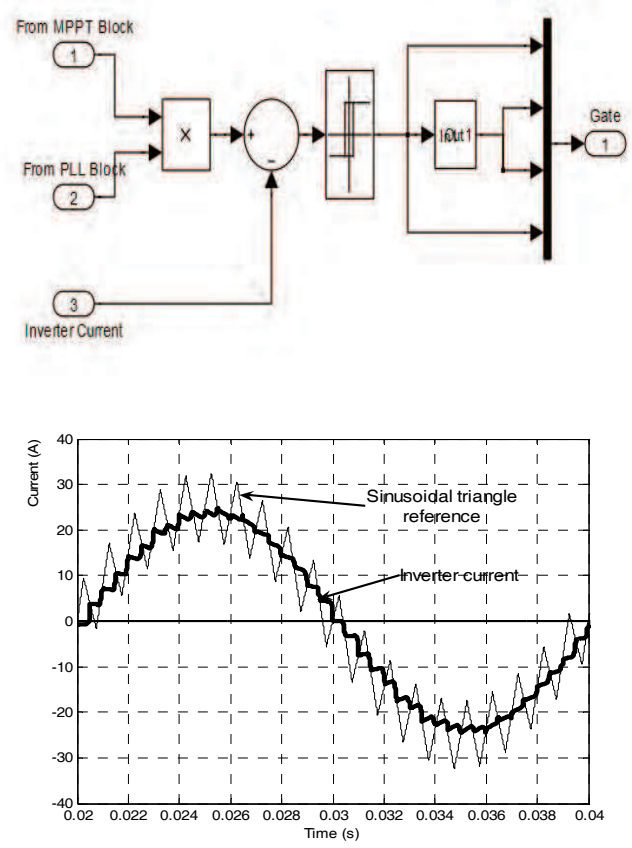

b. Ramp comparison current control

Fig. 10. Modulating techniques for current controller used in the simulation

In order to evaluate the operation of power and control circuits, the complete simulation diagram is run under variation of irradiance and temperature. Photovoltaic inverter is connected to the grid and is assumed in parallel with other generation equipment in the grid for supplying the connected grid load. Grid load is set up such a way so that enable to accept all generated power from photovoltaic plant -or in other word- load capacity is set up more than the photovoltaic plant capacity. By this way, whatever power can be generated by photovoltaic plant, it is able to be absorbed by the grid load. 


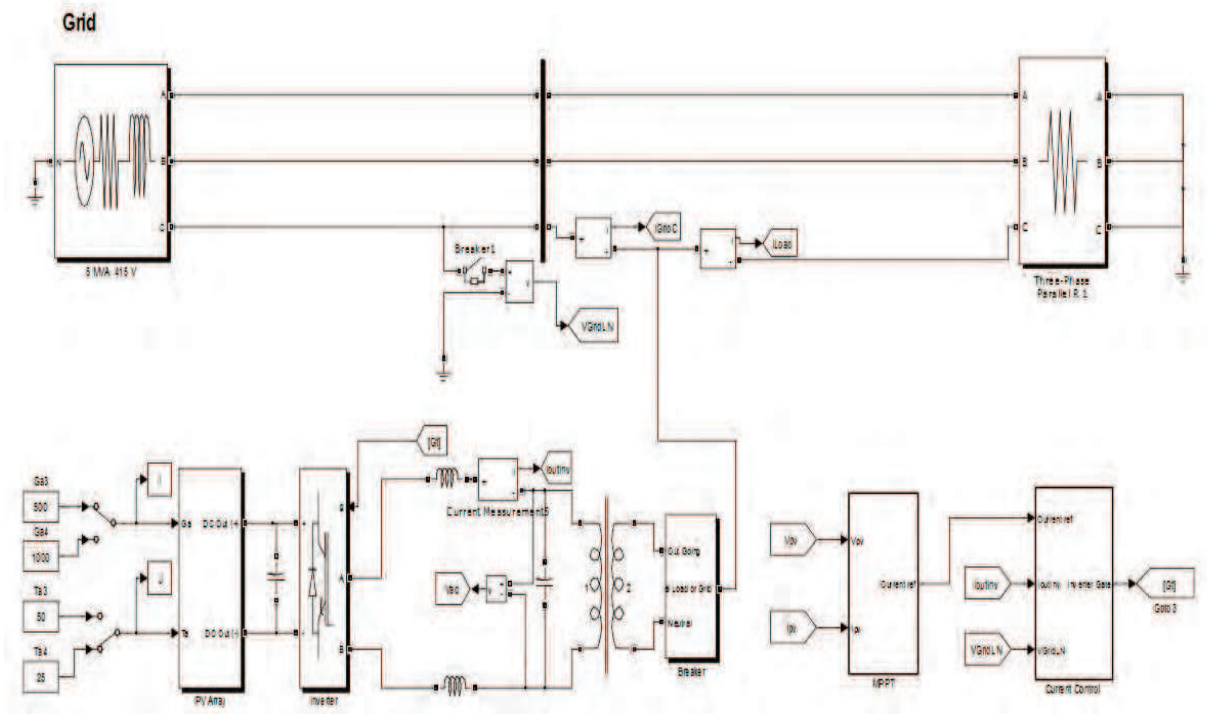

Array \& PV Inverter Power Circuit

MPPT, Current Controller \& Grid Interface

Fig. 11. Complete single-phase grid-tie PV inverter simulation diagram

Operation of MPPT as optimizing mechanism of delivered and injected power to the grid can be seen by measuring the generated power of PV array (dc side) and output of inverter (ac side) in a condition when the inputs of photovoltaic array are varied. MPPT operation indication will appear when the measured value of output power inverter always follows the value of dc power as the output of photovoltaic array. This condition is shown in Fig.12, the values of generated power by PV array correspond to irradiance and temperature level, each combination of their values will give different generated power on array output. It is also shown the value of power measured on output terminal of inverter that always run before the value of generated power that measured on array terminal. For $G_{a}=500 \mathrm{~W} / \mathrm{m}^{2}$ and $\mathrm{T}_{\mathrm{a}}=25^{\circ} \mathrm{C}$ that equivalent with dc output power of array $\mathrm{P}_{\mathrm{dc}}$ around $475 \mathrm{Watt}$, injected power on output terminal of $\mathrm{PV}$ inverter $\mathrm{P}_{\mathrm{ac}}$ shows the same value. When the irradiance is changed to $G_{a}=1000 \mathrm{~W} / \mathrm{m}^{2}$ on the same temperature with equivalent to $P_{d c}=500 \mathrm{Watt}$, the trend of $\mathrm{P}_{\mathrm{ac}}$ curve tend to this value. These behaviors indicate that the MPPT mechanism works properly.

The current drawn by connected load is supplied from both grid and PV plant. It is different with paralleling two sources such as transformers or generators in supplying a connected load, where capacity and internal impedance are parameter that determine load sharing between both equipments, load current drawn by PV inverter in a grid is not depend on its capacity. Optimum power can be sent to grid as long as there is sufficient power generated by the plant. Figure 13 shows simulation result how a connected load current is supplied from both grid and PV inverter. Initially, whole load drawn by the constant load is supplied 
from the grid. At point when the PV plants switched on, the PV plant current increase and the current from grid decrease and then go to steady condition untill the PV plant is switched off.
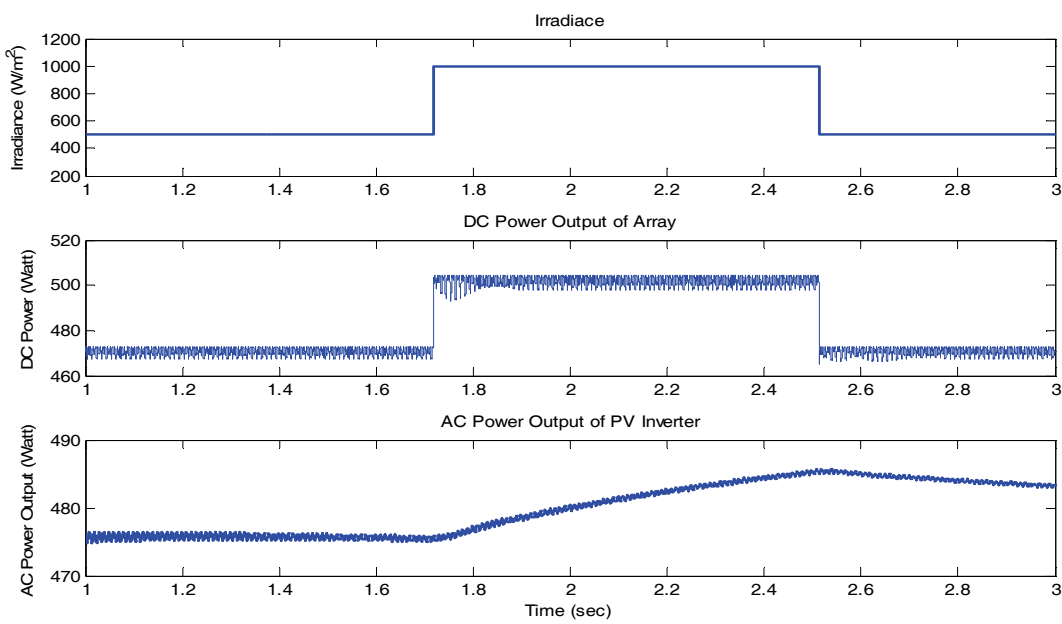

Fig. 12. MPPT operation is indicated by the trend of ac power output that is always tend to dc power value

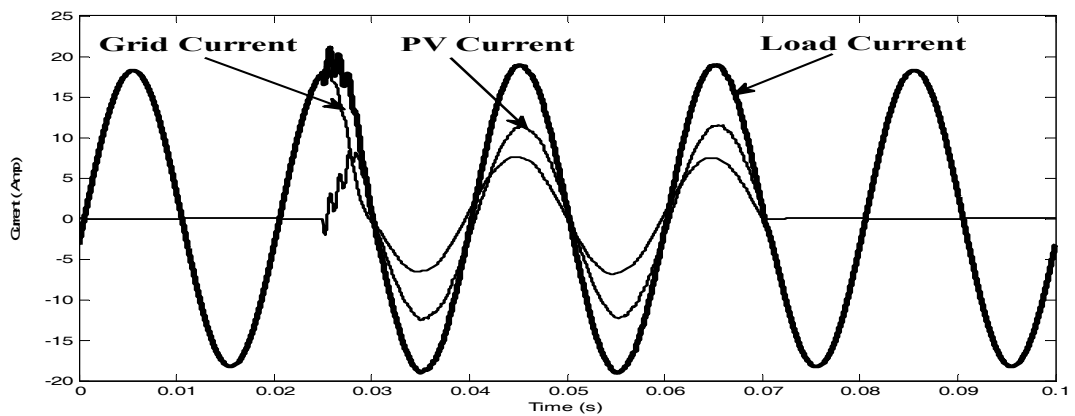

Fig. 13. Load current sharing between grid and plant on phase $a$ when plant switched

\section{Observation and measurement results of a laboratory scale PV distributed generation operation using single phase inverter}

In this section, some power behaviors from the operation of inverters in a PV plant such as power quality, voltage stability, harmonics, wave form distortion and load sharing characteristic will described. The schematic diagram of the plant is shown in Fig. 13. 


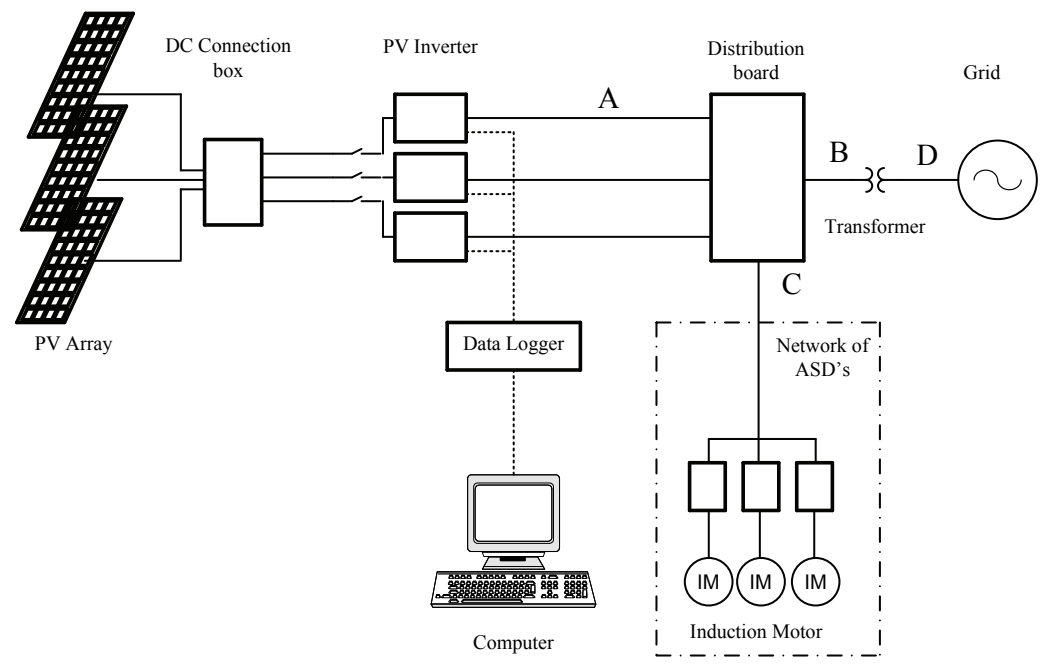

Fig. 13. Diagram of laboratory scale PV generation system

\subsection{System Description}

The PV plant is located at the position of $1^{\circ} 33^{\prime} 37.52^{\prime \prime} \mathrm{N}$ and $103^{\circ} 38^{\prime} 30.87^{\prime \prime} \mathrm{E}$, consists of a PV array of 24 modules with totally $5 \mathrm{kWp}$ installed capacity. The PV array is then divided into three sub arrays in order to configure the plant type as a string-inverter configuration. Three unit PV inverters of 700 Watt each are then fed by these array outputs. The sub arrays are connected to PV inverters by a DC connection box where the modules are configured in serial to obtain the DC voltage requirement for the PV inverter. The 70-meter long and 10 mm2 DC cable links DC connection box and PV inverters. Each single-phase inverter is connected to each phase of the grid to form the three-phase connection. Output side of PV inverters are fed to an interconnection switchboard where the grid integration, measurement, and local load supply of resistive and adjustable speed drives are connected.

The three units string PV inverters role as distributed generator (grid tied inverter). The inverters are from single stage type with H-bridge topology; operate in carrier based pulsewidth modulation of $14 \mathrm{k}-\mathrm{Hz}$ carrier frequency. MPPT mechanism, current control, synchronization, and grid impedance monitoring complete each PV inverter. Connecting or disconnecting the PV inverter to the grid is a part of the control system; it is accomplished based on the availability of power from PV array and in coordination with the internal grid monitoring system. Some parameters of the PV inverter are described in Table 1.

\begin{tabular}{llll} 
Input & \multicolumn{3}{c}{ Output } \\
\hline $\mathrm{V}_{\mathrm{DC}}$ Max, Volts & 250 & $\mathrm{~V}_{\mathrm{AC}}$ nom, Volts & 250 \\
$\mathrm{~V}_{\mathrm{DC}}$ MPP, Volts & $119-200$ & $\mathrm{f}_{\mathrm{AC}}$ nom, Hz & $50 / 60$ \\
$\mathrm{I}_{\mathrm{dc}}$ Max, Amps & 7 & $\mathrm{P}_{\mathrm{AC}}$ nom, Watts & 700 \\
& & $\mathrm{I}_{\mathrm{AC}}$ nom, Amps & 3 \\
& & Cos $\Phi$ & 1 \\
\hline
\end{tabular}

Table 1. PV Inverter parameters for the observation 


\subsection{Voltage Stability}

Figure 14.a shows the power output, the line to neutral voltage of an inverter and the total power output of the PV plant during a whole day operation that measured at the point of common coupling of the PV plant and the grid. The inverter starts to operate and connect to the grid when the generated powers reach the minimum predetermined value. The injected power to the grid is begin to increase along with the increasing of the solar power density in the morning, tend to constant in the middle of the day, and then decrease in the afternoon. The maximum injected power from the phase A-connected inverter is $503.90 \mathrm{Watt}$, phase B inverter 481.6 Watt and phase C inverter 453.10 Watt; coincide with the maximum power output of the PV plant of 1439.0 Watt. With the installed capacity of each inverters and plant are 700 and 5000 Watt, the values indicate the maximum capacity factors of the PV inverter and the plant on that day measurement are $71.98 \%$ and $28.78 \%$ respectively.

Figure 14.b is a portion of Fig.14.a is a 180 minutes measurement during peak power time, the figure shows the phase-A line voltage and the injected power from the connected inverter. It is shown that variation of injected power to the grid caused by variation of extracted power density from about 100 Watt to 400 Watt is followed by variation of voltage level on the plant terminal as about $3 \mathrm{~V}$. The shape of the curves shows that during the measurement interval, the variation of the plant parameters occur very often along with the atmospheric dynamic condition. This condition, further implicates to voltage stability problem. Figure 15 is a histogram obtained from measurement data of Fig. 14.a; it is performed to show the frequency of occurrence of various power levels (in range of 50 Watt each) of the PV plant, data is collected for every 7 second. The number of power levels and the frequency of occurrence on each power levels in the histogram indicate that the grid is susceptible to voltage stability problem concerning to operation of a PV plant. The instability of voltage in this case is more important along with the increasing capacity of the plant and the fact that the atmospheric dynamic condition is occurring along the whole day.

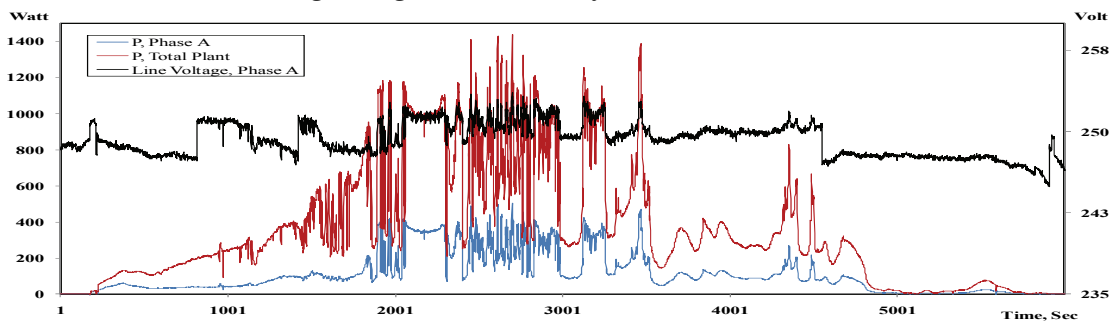

a. Line voltage, injected power on a phase of the grid and total injected power of the PV plant

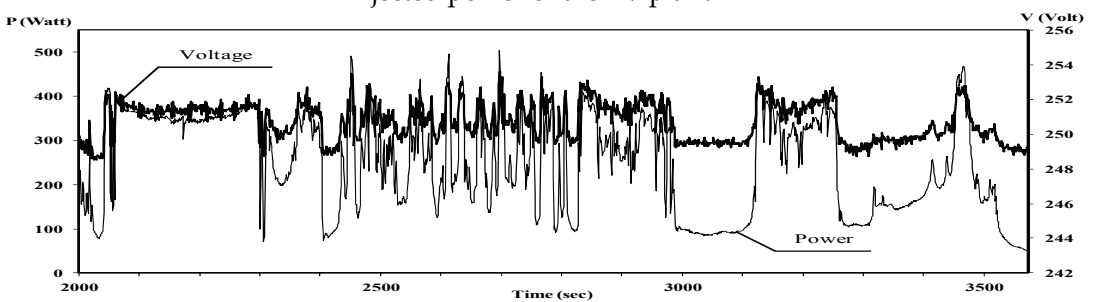

b. Line voltage, injected power on a phase $\mathrm{A}$ for 180 minutes measurement during the peak time

Fig. 14. $\mathrm{P}$ and $\mathrm{V}_{\mathrm{LN}}$ on the point of common coupling between the PV Inverter and Grid 


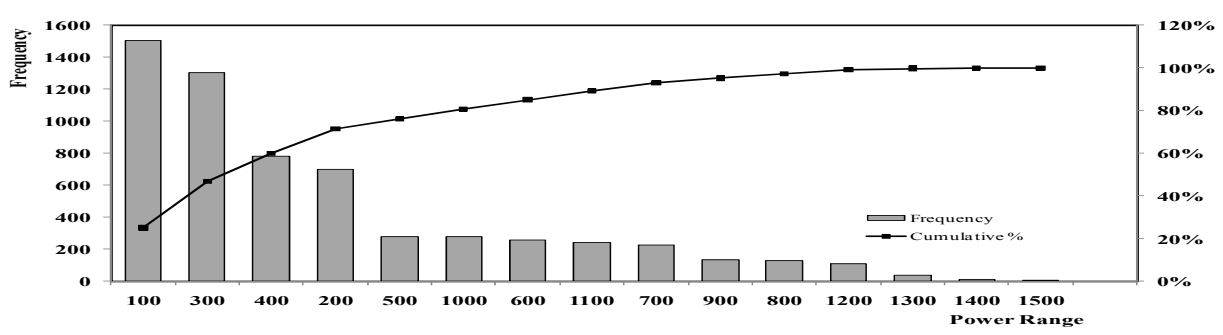

Fig. 15. Pareto diagram of various power levels generated from PV Inverter

Variation of injected power is also followed by variation of other power parameters such as $\operatorname{Cos} \theta$ and power factor (PF). Their values according to magnitude of power level that injected to the grid are shown in Fig. 16. During injecting relative low power, $\cos \theta$ and power factor tend to decrease and then increase along with the increasing of generated power. Optimum $\cos \theta$ and power factor are reached when generated power is more than $50 \%$ of PV inverter rated. The measurement result indicates the importance for employing the PV inverter near to its rated power.

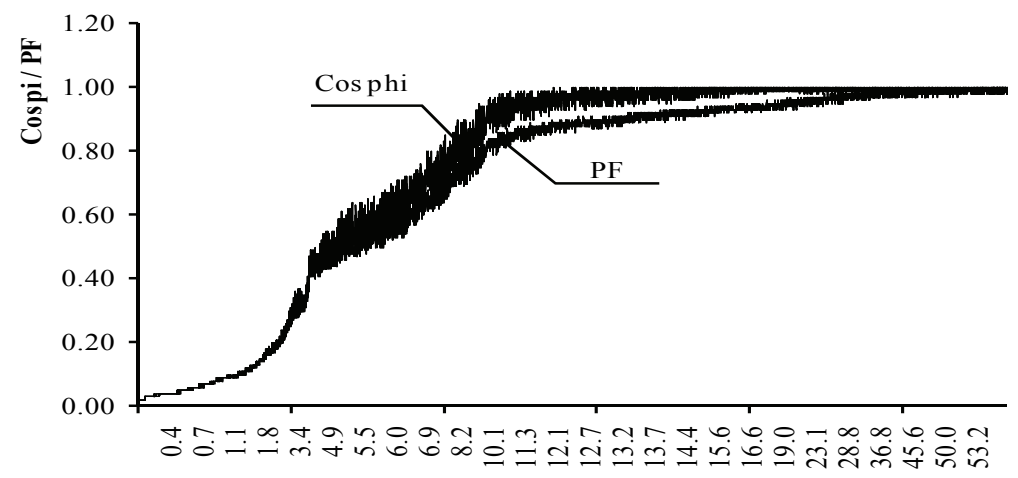

$\%$ Rated Power

Fig. 16. $\cos \theta$ and power factor as function of generated and injected power

\subsection{Waveform and harmonics distortion}

Other aspect in PV plant operation using grid tied inverters is the appearance of distortion on the wave shape of power parameters where the plant is connected. In injecting the generated power to the grid, the control of the PV inverter forces the current to flow with the wave shape is fashioned to follow and in phase with the grid voltage. Nevertheless, depend on the design component of the inverter and the injected control type that used; the resulted current may draw a distorted wave that indicates the existence of harmonics, the voltage and current shape of a single phase PV inverter during operate is shown in Fig.17.

The level of the harmonics distortion -presented as the total harmonics distortion (THD) on the inverters current is varying during operation; its value shows a relation with the level of generated and converted power from the array. Low harmonics content appears during 
high power conversion operation and in contrary high harmonics content during low power operation. However, an anomaly appears during low power operation due to nonlinearity of the inverter components, in a certain condition, harmonics tend to increase while in the other one, tend to decrease. A measurement result that describes the plant behaviors is shown in Fig. 18. The figure presents the harmonics measurement of the inverter's current and connected grid voltage as function of time during a day operation.

During connected to the grid, harmonics contents on the produced current of the PV inverter interact with the grid impedance causes the voltage where the inverter is connected is distorted. Further, the interaction between these two distorted waves causes the power factor on the connection point is influenced. Effect of the voltage and current distortion to the power factor can be obtained from the following relations:

where:

$$
P F=\frac{P_{\text {avg }}}{V_{1 r m s} \cdot I_{1 r m s}} \frac{1}{\sqrt{1+T H D_{v}^{2}} \cdot \sqrt{1+T H D_{i}^{2}}}
$$

and

$$
D_{f}=\frac{P_{\text {avg }}}{V_{1 r m s} \cdot I_{1 r m s}}=\operatorname{Cos} \theta
$$

$$
F_{f}=\frac{1}{\sqrt{1+T H D_{v}^{2}} \cdot \sqrt{1+T H D_{i}^{2}}}
$$

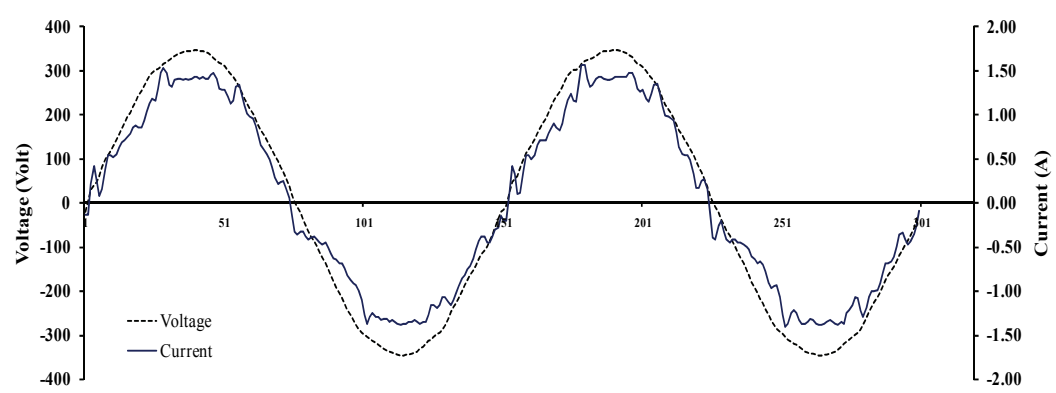

Fig. 17. Waveform of current output and voltage on terminal of single phase PV inverter

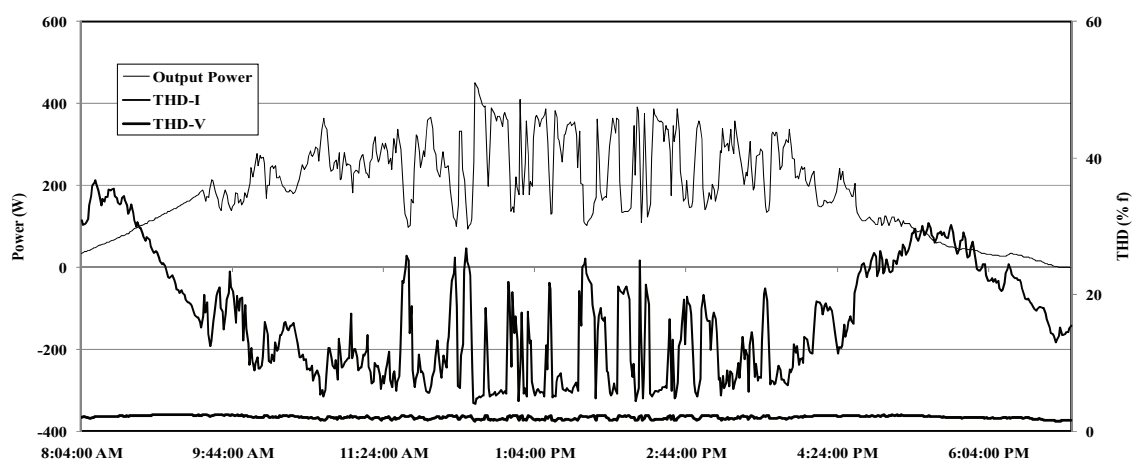

Fig. 18. Harmonics measurement of the inverter's current and connected grid voltage 
The equations show that the power factor PF consists of two components; the displacement factor $D_{f}$ that depends on the phase shift between voltage and current, and the form factor $F_{f}$ that depends on the wave shape of voltage and current. According to Fig. 17, it is obvious that the power factor of the PV inverter is dominantly influenced by form factor. Low level of displacement factor of the PV inverter is caused by the reality that the control current of PV inverter is designed so that the current and voltage of the inverter are always in phase.

As the part of the distributed generation, PV plant operation must comply with the power quality requirement as described in various power quality standards. On the subject of harmonics contents, the standards generally present an acceptable maximum value of each harmonics order of injected current and voltage in the grid. For example, IEEE standard 5191992 [25] and 1547-2003 [26] limits the individual harmonics in some groups of range for the first 40 harmonics and give a maximum level of the total demand harmonics distortion of the injected current. Regarding to the distortion and converted power level relation of PV inverter as described, it is obvious that operation of inverters in the PV plant causes the grid is distorted, especially by the current harmonics in low power operation. In other words, refers to capacity factor of inverter, we can say that the PV inverters will draw high contents of harmonics if they are employed in low capacity factor. Further, in order to comply with the limitation of injected current harmonics, it is important to perform the suitability combination between the capacity of both inverter and PV array. Minimum output of PV array during operation cycle should not be smaller than a level in which PV inverters operate in low capacity factor and produce harmonics that excess the accepted standard. Besides the conversion efficiency, harmonics and distortion factor should be considered in designing the array installed-capacity for a certain capacity of PV inverter.

\subsection{PV plant and grid interaction}

Once a PV inverter is connected to the grid, it become the part of the entire power system and associated load. Further, both system influence and interact each other, including power sharing in supplying a connected load. Figure 19 and 20 shows the measurement results of current on phase R at point A, B and C -as shown in Fig. 13 -when the system is supplying the local load. Two types of variable load are taken as test case: a network of adjustable speed drives (ASDs) and a resistive load. For both types of load, load current is set up so that their magnitudes are larger than the magnitude of current from the PV plant, direction of current is than observed in order to show load sharing between PV plant and grid.

During steady state operation of the ASD, measurement in point C shows the typical current shape of DC converter in input side of ASD (three-phase diode bridge rectifier). At the instant when the ASD draws input current, injected current from PV plant to the grid is reduced; and becomes supply current for the ASD. The wave shape of the injected current to the grid is in form of a distorted sinusoidal with a portion is cut by the three phase bridge rectifier current shape. In this condition, harmonics spectrum of current measured at the grid are different with the usual ASD current shape; a sinusoidal spectrum in with the spectrum of the three phase diode bridge rectifier is cut out. If the amount of the current for the ASD cannot be fulfilled fully by current from the PV plant, thus a portion of current flows from the grid, harmonics spectrum of current in the grid are same as the ASD current spectrum. This condition can be seen by the appearances of negative portion on the shape of 
the grid current in each half of fundamental frequency, that mean that the current flow in opposite direction with the reference current flow. The same case is happen when the resistive load is connected.

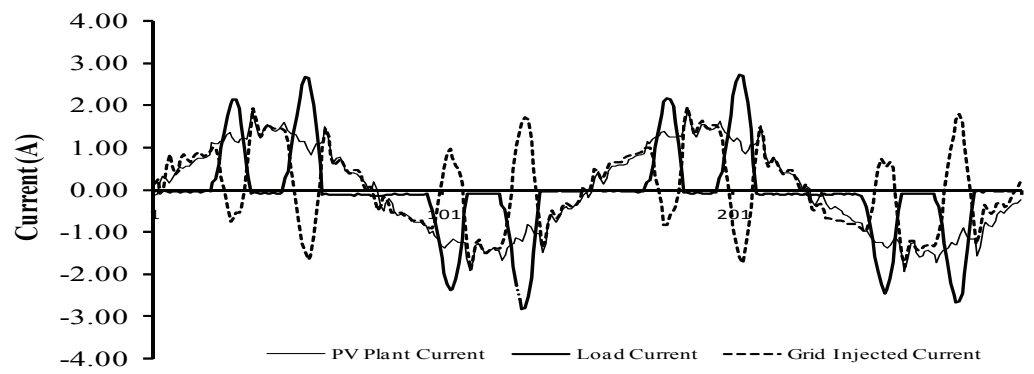

Fig. 19. PV plant, load and grid current with ASD type load is operated

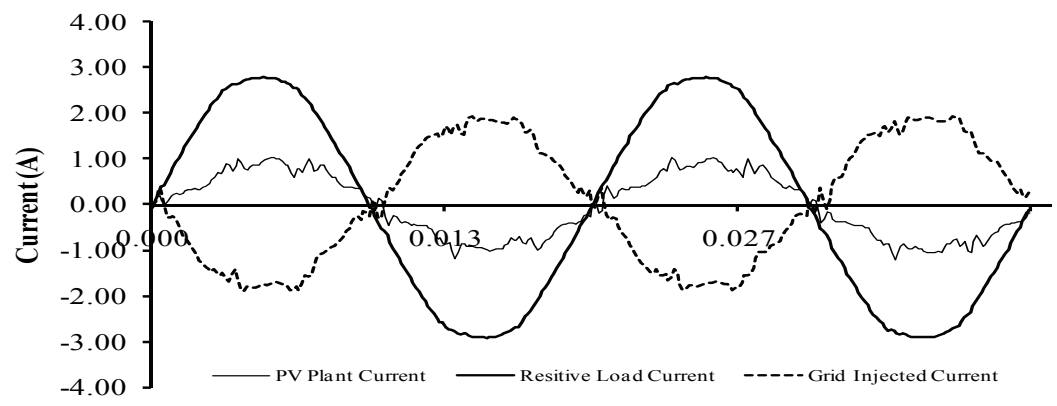

Fig. 20. PV plant, load and grid current with resistive type load is operated

\section{Conclusion}

In this chapter, some aspects in photovoltaic conversion using single-phase PV inverters, their involvement as a part of the distributed generation and the role of some embedded parts and functional devices that supporting this role has been described. Modeling of such parts and functions for digital simulation has also been presented. Through the simulation, some aspects of the PV inverters operating behavior -for certain reasons cannot be obtained from direct observation- can be evaluated.

This chapter has also presented some of the characteristics of the single-phase PV inverters in real operation, primarily in the characteristics of the power generated and the interactions with the distribution network where they are connected. Observation and measurement show that the voltage stability and waveform distortion are some problems that appear in the operating a PV plant as distributed generation. The distortion influences the other power output parameters of the plant such as the grid voltage and power factor. The power factor of the inverter output is dominantly caused by form factor rather than displacement factor and the current harmonics highly involved in the condition. It has been shown that capacity of PV inverters should be chosen so that they operate in a plant with high capacity 
factor in order to minimize the appearance of harmonics. Load sharing between the PV plant and the grid for supplying a connected load have also been presented. Finally, the relationship between the compliance capacity of the inverter with the quality of output power has been clarified and the importance for involving the distortion factor in sizing and planning the capacity of photovoltaic plant components have been stressed.

\section{References}

[1] Trends in Photovoltaic Applications. Survey Report of Selected IEA Countries Between 1992 and 2006. International Energy Agency Photovoltaic Power Systems, IEA-PVPS-T1-16:2007. [Online]. Available: www.iea-pvps.org

[2] M. Oliver, T. Jackson, "Energy and Economic Evaluation of Building-integrated Photovoltaic," Energy vol. 26. pp.431-439. 2001.

[3] V. Acquaviva. “Grid-connected Rooftop PV Systems for Reducing Voltage Drop at the End of the Feeder - A Case Study in Corsica Island," Energy, vol. 25. pp. 741756. 2000.

[4] A.S. Jhutty, "System implication of embedded generation and its protection and control," IEE Colloquium Birmingham, Feb 1998

[5] L. Borle, M. Dymond, and C.V. Nayar, "Development and testing of a $20 \mathrm{~kW}$ grid interactive photovoltaic power conditioning system in Western Australia", 1996.

[6] G.M. Masters, "Renewable and Efficient Electric Power Systems". Hoboken New Jersey: John Wiley \& Sons Inc., 2004.

[7] F. Blaabjerg, Z. Chen and S. B. Kjaer, "Power Electronics as Efficient Interface in Dispersed Power Generation Systems." IEEE Trans. on Power Electronics 2004; vol.19 no. 5. Pp. 1184-1194. 2000.

[8] J.H.R. Enslin, Peter J. M. Heskes, "Harmonic Interaction Between a Large Number of Distributed Power Inverters and the Distribution Network," IEEE Trans. On Power Electronics, vol. 19, no. 6, November 2004.

[9] P.J.M. Heskes, "Power Quality Behaviour of Different PV Inverter Topologies" PCIM-2003 The 24th International Conference, Nierenberg Germany.

[10] A. Woyte, V.V. Thong VV, R. Belmans, and J. Nijs J., "Voltage Fluctuations on Distribution Level Introduced by Photovoltaic Systems," IEEE Trans. on Energy Conversion; vol. 21 no.1. pp. 202-209. 2006.

[11] Luque A. Handbook of Photovoltaic Science and Engineering. West Sussex England: John Wiley and Sons Inc., 2003.

[12] E. Koutroulis, K. Kalaitzakis, and N. C. Voulgaris, "Development of a Microcontroller-Based, Photovoltaic Maximum Power Point Tracking Control System," IEEE Trans. On Power Electronics, vol. 16, No. 1, Jan 2001.

[13] T. Esram, "Comparison of Photovoltaic Array Maximum Power Point Tracking Techniques," IEEE Transaction on Energy Conversion, vol. 22 no.2. pp. 439-449. 2007

[14] M.A.S.Masoum, H.Dehbonei, "Theoretical and Experimental Analyses of Photovoltaic Systems With Voltage- and Current-Based Maximum Power-Point Tracking," IEEE Trans. on Energy Conversion, vol.17, no.4. pp. 514-522. 2002.

[15] S.H. Ko, S.R. Lee, and H. Dehbonei, "Application of Voltage- and CurrentControlled Voltage Source Inverters for Distributed Generation System," IEEE Trans. Energy Conversion, vol. 21, no.3, pp. 782-792, 2006. 
[16] M. Calais, J. Myrzik, T. Spooner, V.G. Agelidis, "Inverters for Single-phase Grid Connected Photovoltaic Systems - An Overview," Proc. IEEE PESC'02, vol. 2. 2002. Pp 1995-2000.

[17] F. Blaabjerg, Z. Chen and S.B. Kjaer, "Power Electronics as Efficient Interface in Dispersed Power Generation Systems," IEEE Trans. on Power Electronics, vol. 19, no.5. pp. 1184-1194, 2004.

[18] Y. Xue, L.Chang, S. B. Kjær, J. Bordonau, and T. Shimizu, "Topologies of SinglePhase Inverters for Small Distributed Power Generators: An Overview," IEEE Trans. on Power Electronics, vol. 19, no. 5, pp. 1305-1314, 2004.

[19] S.B. Kjær, J.K. Pedersen, and F. Blaabjerg, "A Review of Single-Phase GridConnected Inverters for Photovoltaic Modules," IEEE Trans. On Industry Application, vol.41, no.5, pp. 1292-1306, 2005.

[20] H. Yamashati, K. Tamahashi, M. Michihira, A. Tsuyoshi, K. Amako, M. Park, “A Novel Simulation Technique of the PV Generation Systems using Real Weather Conditions," IEEE 2002, PCC-Osaka 2002.

[21] S. Liu and R. A. Dougal, "Dynamic multi-physics model for solar array," IEEE Trans. on Energv Conversion, Vo1.17, No.2, pp.285-294, June 2002

[22] A. Cow and C.D. Manning, "Development of a photovoltaic array model for use in power-electronics simulation studies", IEE Proc. Elecrr. Power Appl., Vol. 146, Na.2, pp.193-200, March 1999

[23] W. Xiao, W.G. Dunford, A. Capel, “A Novel Modelling Method for Photovoltaic Cells" 35th Annual IEEE Power Electronics Specialists Conference Aachen, Germany. 2004

[24] D. M. Brod and D. W. Novotny, "Current Control of VSI-PWM Inverters," IEEE Trans. on Industry App. vol. IA-21, no. 4, pp. 562-570, May/Jun 1985.

[25] IEEE Standard for Interconnecting Distributed Resources with Electric Power Systems, IEEE Standard 1547, 2003.

[26] IEEE Standard for Interconnecting Distributed Resources with Electric Power Systems, IEEE Standard 519, 2003.

[27] The Mathwork, accelerating the pace of engineering and science, http://www.mathworks.com 


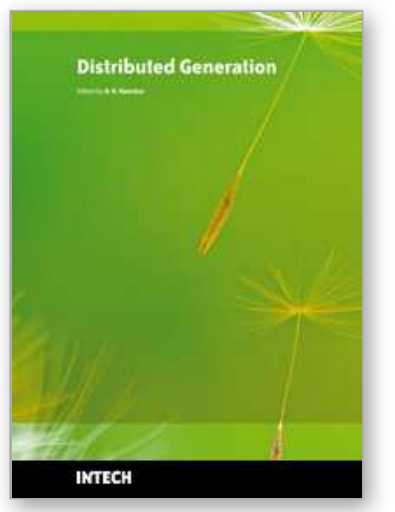

\author{
Distributed Generation \\ Edited by D N Gaonkar
}

ISBN 978-953-307-046-9

Hard cover, 406 pages

Publisher InTech

Published online 01, February, 2010

Published in print edition February, 2010

In the recent years the electrical power utilities have undergone rapid restructuring process worldwide. Indeed, with deregulation, advancement in technologies and concern about the environmental impacts, competition is particularly fostered in the generation side, thus allowing increased interconnection of generating units to the utility networks. These generating sources are called distributed generators (DG) and defined as the plant which is directly connected to distribution network and is not centrally planned and dispatched. These are also called embedded or dispersed generation units. The rating of the DG systems can vary between few $\mathrm{kW}$ to as high as $100 \mathrm{MW}$. Various new types of distributed generator systems, such as microturbines and fuel cells in addition to the more traditional solar and wind power are creating significant new opportunities for the integration of diverse DG systems to the utility. Interconnection of these generators will offer a number of benefits such as improved reliability, power quality, efficiency, alleviation of system constraints along with the environmental benefits. Unlike centralized power plants, the DG units are directly connected to the distribution system; most often at the customer end. The existing distribution networks are designed and operated in radial configuration with unidirectional power flow from centralized generating station to customers. The increase in interconnection of $D G$ to utility networks can lead to reverse power flow violating fundamental assumption in their design. This creates complexity in operation and control of existing distribution networks and offers many technical challenges for successful introduction of DG systems. Some of the technical issues are islanding of DG, voltage regulation, protection and stability of the network. Some of the solutions to these problems include designing standard interface control for individual DG systems by taking care of their diverse characteristics, finding new ways to/or install and control these DG systems and finding new design for distribution system. DG has much potential to improve distribution system performance. The use of DG strongly contributes to a clean, reliable and cost effective energy for future. This book deals with several aspects of the DG systems such as benefits, issues, technology interconnected operation, performance studies, planning and design. Several authors have contributed to this book aiming to benefit students, researchers, academics, policy makers and professionals. We are indebted to all the people who either directly or indirectly contributed towards the publication of this book.

\title{
How to reference
}

In order to correctly reference this scholarly work, feel free to copy and paste the following:

Muh. Imran Hamid and Makbul Anwari (2010). Single-Phase Photovoltaic-Inverter Operation Characteristic in Distributed Generation System, Distributed Generation, D N Gaonkar (Ed.), ISBN: 978-953-307-046-9, InTech, Available from: http://www.intechopen.com/books/distributed-generation/single-phase-photovoltaic-inverteroperation-characteristic-in-distributed-generation-system 
open science | open minds

InTech Europe

University Campus STeP Ri

Slavka Krautzeka 83/A

51000 Rijeka, Croatia

Phone: +385 (51) 770447

Fax: +385 (51) 686166

www.intechopen.com
InTech China

Unit 405, Office Block, Hotel Equatorial Shanghai

No.65, Yan An Road (West), Shanghai, 200040, China

中国上海市延安西路65号上海国际贵都大饭店办公楼 405 单元

Phone: +86-21-62489820

Fax: +86-21-62489821 
(C) 2010 The Author(s). Licensee IntechOpen. This chapter is distributed under the terms of the Creative Commons Attribution-NonCommercialShareAlike-3.0 License, which permits use, distribution and reproduction for non-commercial purposes, provided the original is properly cited and derivative works building on this content are distributed under the same license. 